\title{
INFORMATION SUPPORT OF MANAGEMENT OF INTERNATIONAL OPERATIONS
}

\author{
Kateryna Datsko \\ Associate Prof. PhD, Kryvyi Rih Economic Institute of Kyiv National Economic University \\ named after Vadym Hetman, \\ e-mail: datsko_kp@kneu.dp.ua, orcid.org/0000-0002-8617-6925, Ukraine \\ Juan Campechano Covarrubias \\ Prof., SNTE Sindicato National de Trabajadores de la Educacion, \\ e-mail: deduc.jcc@snte.org.mx, Mexico
}

\begin{abstract}
The article summarizes the constituent elements of the information provision of management of international operations. The key problems faced by enterprises in implementation of international activities under the conditions of instability of economic and political processes were identified.
\end{abstract}

Keywords: international operations, accounting software, analysis, management.

DOI: http://dx.doi.org/10.23856/2409

\section{Introduction}

Under the conditions when the world demonstrates low economic growth indicators, while developing countries continue to integrate and deepen financial markets, it is necessary to perform management of risks and factors that influence the world economic processes. The development of processes of integration and globalization contribute to promoting scientific research aimed at improving the effectiveness of the implementation of international operations and foreign trade activities of industrial enterprises using the advantages of international economic integration. The definition of the main strategic directions of integration into the world economic space seems important. Defining priority forms of development of foreign economic activity in the context of international integration needs further research and development. The system of management methods in the framework of international operations at micro and macro levels needs to be developed and improved. The above issues identified relevance and focus of the study.

\section{The economic essence of international operations}

Foreign economic activity of enterprises is implemented by the international commercial operations, which represent a set of operations on exchange of goods in material form, different types of services, transactions on the exchange of products of intellectual activity. All these operations should result in profit, that is, these transactions are of commercial nature. Commercial operations do not include operations related to the provision of humanitarian assistance, keeping international relations in the fields of education, culture, sports, etc.

Grouping objects of research based on their characteristics allows to identify key areas for further research and to identify the characteristics of a particular category. We consider it is appropriate to present the classification of international commercial transactions. 
Fig.1 shows the conventional classification of international transactions that are of a commercial nature.

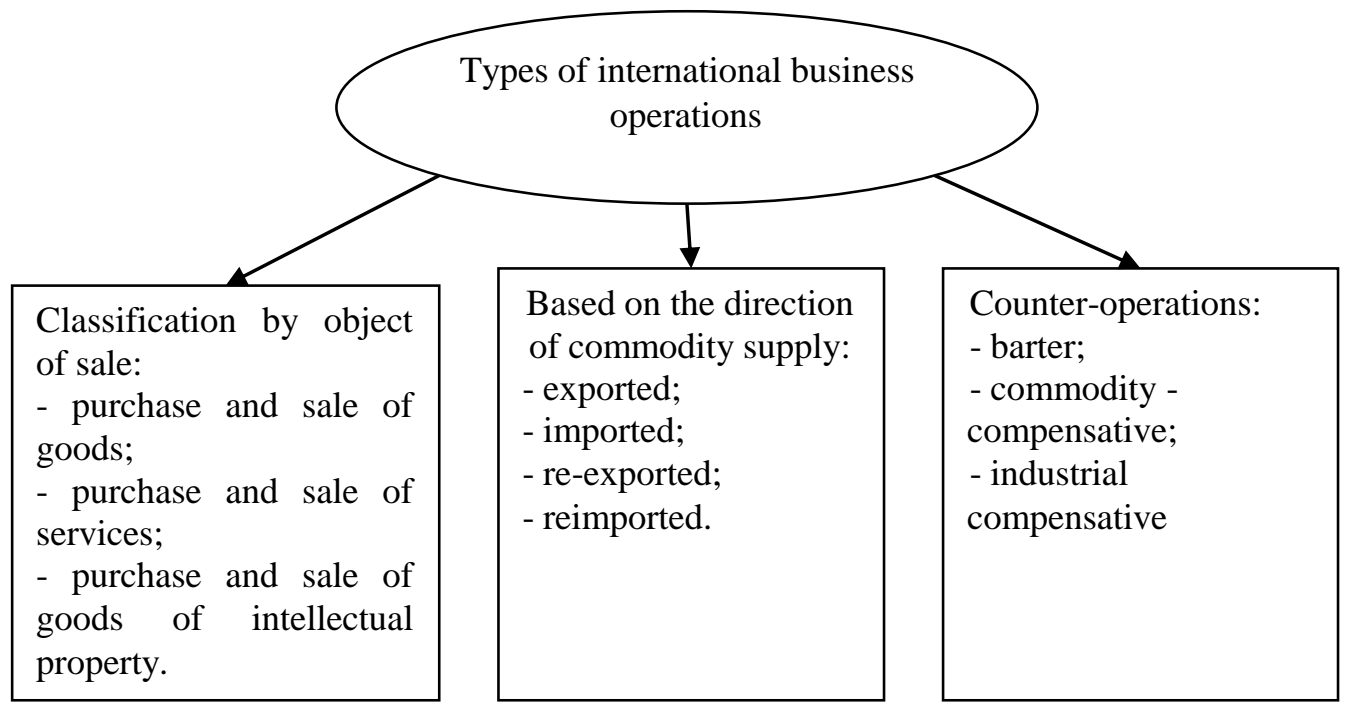

Fig. 1. Classification of international commercial transactions

[summarized by the author]

The classification of international transactions specifies that the export-import operations are the basis for the international activity of the country. This provision is confirmed by statistical data. Let us consider the statistics according to the volume of exportimport operations in the leading countries of the world.

The development of the international market indicated to continued positive momentum of international operations, as evidenced by the statistics of export and import transactions of the countries-leaders in the implementation of international operations in the world (Table 1).

Statistics shows that the trade balance indicators are different in the leading countries of the world. So, in the European Union there is a phenomenon of strong export, but in the U.S. import prevails over export operations, which indicates the passivity of the trade balance, which is reached by a too high level f imported goods in the country in terms of technical equipment of production capacities. In turn, this country ranks third in the world in the export of its goods.

We should note that the countries with developed market economy and a relatively stable political situation in the country are the leaders of the export-import activities. However, these types of international commercial operations have their own characteristics and, accordingly, their own problems of management. 
Table 1

Statistics of export-import operations in the world for 2016 (according to the data of the Central Intelligence Agency), USD mln.

\begin{tabular}{|l|c|c|}
\hline \multicolumn{1}{|c|}{ Country } & Export volume & Import volume \\
\hline USA & 2259000 & 2244000 \\
\hline China & 1471000 & 2205000 \\
\hline Germany & 2011000 & 1437000 \\
\hline Japan & 1283000 & 987600 \\
\hline UK & 641400 & 629800 \\
\hline France & 412100 & 581600 \\
\hline Hong Kong & 505400 & 525400 \\
\hline Canada & 487700 & 509500 \\
\hline South Korea & 402400 & 419000 \\
\hline India & 509000 & 405100 \\
\hline Netherlands & 271600 & 402400 \\
\hline Mexico & 460100 & 376300 \\
\hline Italy & 359300 & 372800 \\
\hline Spain & 436300 & 287900 \\
\hline Singapore & 266300 & 271300 \\
\hline Belgium & 353300 & 251700 \\
\hline Taiwan & 250800 & 248700 \\
\hline United Arab Emirates & 314800 & 246900 \\
\hline Switzerland & 316000 & 243400 \\
\hline USA & 301100 & \\
\hline
\end{tabular}

\section{The problems of management of international operations}

The combination of theoretical approach (modern systems of management of international operations) and practical studies of the dynamics of international transactions in the world, identified the issues of management of international operations.

The modern economic processes produce negative impact on the functioning of the international market and the development of operations of foreign trade. Let us define global constraints in the implementation of international activities:

- the structure of international companies - national monopolies with foreign assets, manufacturing, sales and marketing activities that go beyond one state, or international corporations uniting the national companies of some the states on an industrial and scientifictechnical basis (a multinational company);

- foreign legislation and regulations - the structure of international agreements (contracts); international transport INCOTERMS rules recognized by governmental bodies, law firms and traders around the world as the interpretation of the terms most applicable in international trade;

- rules of international accounting - accounting and financial reporting according to international financial reporting standards; 
- features of insurance of export-import operations - the stipulate a set of types of insurance that provides for the protection of domestic and foreign participants of those or other member firms of international cooperation;

- calculation of cost and global pricing strategy;

- currency fluctuations;

- logistics of international operations;

- communication difficulties and cultural differences;

- political risks;

- the complexity of the supply chain and the risks of labour exploitation;

- world environmental problems.

The fact that foreign economic relations belong to the economic ones defines the methodology of regulation of these relations. Considering the theoretical research we can define the following methods of management of international operations:

- the method of autonomous decision making by entities (to voluntarily engage in foreign economic relations; to carry out any types of international transactions, except those prohibited by law; to conclude the external economic contracts and to identify the obligations on them under the laws, and the like);

- the method of government regulations, according to which the activity of entities is subject to mandatory models of relationships defined by the legislation (the need to obtain export or import licenses; compliance with the rules of payments in foreign currency; the maintenance of order and terms of carrying out of separate kinds of foreign trade operations);

- method of recommendations according to which the state regulates the behavior of subjects of economic relations through the recommended models of the relevant relationships.

\section{The system of information provision for the management of international operations}

For the effective management of international operations, one needs to consider them as a system of international business, that is a system of business relationships and economic transactions which are performed by subjects of managing from two or more countries with the aim of making a profit, confirmed by the foreign economic contracts or agreements.

Considering the development of international relations and existing problems in the international market, it becomes possible to identify the main characteristics inherent to the system of international operations:

- $\quad$ significant increase in turnover under the influence of scientific and technical progress;

- deepening of internationalization;

- global nature of international business is its most important feature: it covers the world system business information exchange, world financial market, global structure technological innovation;

- deepening of the international division of labour;

- change of the structure of goods and services in world trade (an increase in the proportion of products, reduction of raw material);

- appearance of the dependence of some of the subjects of international business from foreign partners;

- considering cultural factors in business, i.e. all the requirements and limitations imposed by the culture of the country to those who are engaged in business there or in business in it; 
- setting up under the influence of scientific and technical progress of deep technological ties between actors in global business.

- acceleration of the objective process of the international division of labor

- goods in international trade are intermediate products, not end products.

Let us summarize the characteristic features of the international operations in the information management system for management of international operations (Fig.2).

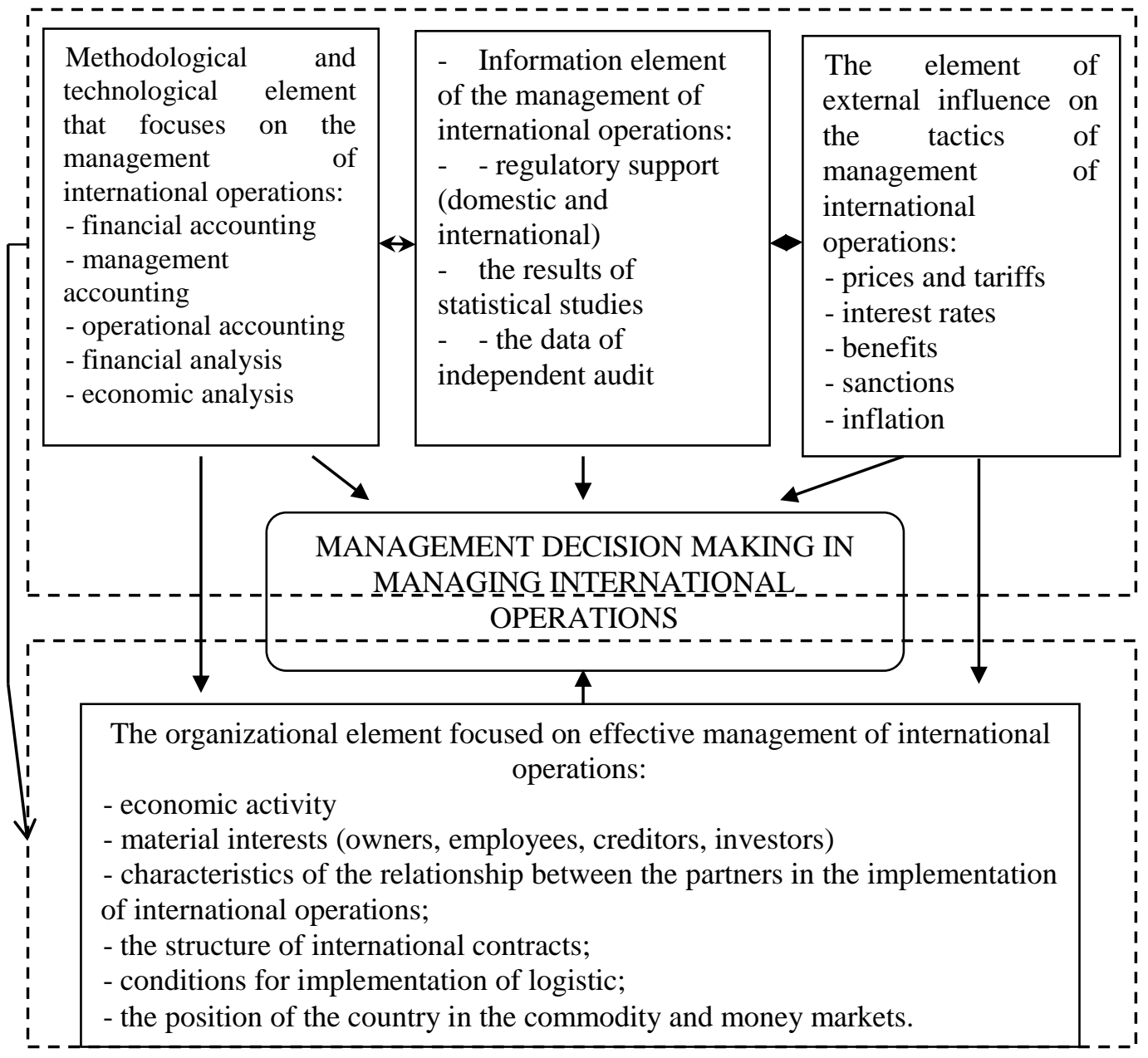

\section{Fig. 2. The mechanism of functioning of system of information support of management of international operations}

These components of information management system comprehensively play the role of effective management mechanism. However, special attention should be paid to the individual components of the system, namely, in the execution of international agreements (contracts) and financing of export-import operations. 
International agreements should ensure the fulfillment of set of international rules in the field of foreign trade. Correctly formulated international agreement makes it possible to avoid or at least greatly reduce the uncertainties of different interpretations of such terms in different countries.

Thus, the international cooperation agreement must identify the following problematic aspects of international cooperation:

- to establish the distribution of transportation costs for delivery of goods between the seller and the buyer, that is, to determine what costs and to what point are borne by the seller, and which, starting from what moment are borne by the buyer;

- to specify the moment of transition of risks of damage, loss or accidental destruction of the goods from the seller to the buyer;

- to determine the date of delivery of the goods, that is, the determination of the time of the actual transfer by the seller to the buyer or its representative - for example, the transport organization - and, therefore, execution or fulfillment of the first of its obligations under the terms of delivery.

The management element that requires more detailed consideration - financing international transactions. This element becomes relevant in a crisis of insolvency of enterprises and lack of available funds. Financing of export-import operations is such an area.

The essence of financing of imports is to ensure the bank payment of the obligations of the importer under the contract at the expense of foreign financial institution, that is to ensure the actual receipt of the deferred payment, unless it was not provided by the exporter, or if his period was not enough for the importer to mobilize the necessary funds. At the same time, the exporter is guaranteed to receive revenue immediately upon the shipment.

The essence of export financing is to ensure that the bank receives from the domestic exporter the funds to cover its cost for production and delivery of the goods until actual receipt of payment from the importer. This scheme allows to produce the required products without diverting its own funds.

These areas of funding are provided by commercial banking institutions. However, the specific conditions of foreign trade resulted in the emergence of special forms of collateral credit. Therefore, the main instruments of financing foreign trade are: factoring, forfaiting, leasing, warranty, counter transactions, project financing, industrial cooperation, joint ventures and participation in the trade of financial institutions. These financing methods are quite common in advanced economies, however, they need improvement in terms of organization and accounting processes in countries that are developing. Therefore, further research should be directed at improving the basic tools of administrative-organizational and financial state support of exports.

The shifts of emphasis of accounting as the basis of information management international operations require further study of accounting mechanisms. In turn, the core is the organizational element that determines the particular relationship of enterprises in the process of international trade. Therefore, organizational features in terms of international agreements (contracts), organization of the logistics part of international transactions and methods of financial provision of their implementation require further research.

\section{State support of export operations}

World laws of economics determine that the primary purpose of the development of international activities is the promotion of exports of own products, creating a trade surplus 
and attracting foreign capital into the country. To support export enterprises, each state runs a series of measures to stimulate domestic export.

The concept of export promotion emerged in the late nineteenth century, laying the foundations for the formation of state policy of export promotion as a component of foreign policy. The reasons for this occurrence can be considered as multiple crises of overproduction in the leading countries of the world and the formation of the neomercantilist trade policy in some countries. The German scholar G. Vilitskyi defines export promotion as a combination of such measures that give individual exporters the incentive to improve their export turnover.

Swiss Professor D. Lefebvre considers government activities, with a clear or classified purpose of physical and (or) increase the cost of exports to be export promoting actions. Those incentives that do not purposefully, but still directly affect particular exporters, increasing their exports, are thus excluded from conceptual construct.

Scientific researches distinguish the French and the German models due their polarity in relation to the role of the state in the process of export promotion. Germany adheres to the principles of subsidiarity of state intervention (through delegation of authority), liberalism and decentralization, while France defends ideas of close coordination, planning, active state intervention in economic life and centralization. Given the Ukrainian experience of centralized management of the economy, and the need to build an aggressive model of export promotion, let us define the main ways of state support of export operations:

- implementation of credit programs to support exporters. Credit support is provided from the state budget through authorized banks;

the operations of export credit insurance, direct investment, foreign economic contracts. All of these operations, loans and investments are subject to insurance against noncommercial risks, and if necessary - they can be reinsured;

- implementation of partial compensation of interest rates on export credits. Compensation is based on the difference in lending rates in the country of the exporter and the buyer;

- providing exporters with loans from the state budget for payment of insurance claims. Loans are provided under insurance contracts for export loans, investments and foreign economic contracts. They are aimed at minimization of commercial and non-commercial risks that could disrupt the Ukrainian exporters;

- the government provides warranties to ensure compliance with the debt obligations of the exporters;

- export orders for the production of products that provides manufacturers of such products guaranteed sales of their products under favorable conditions. In the case the enterprise gets export order the state may participate in export credit insurance within the state standards of subsidies, and large orders, providing long-term financing on the part of the buyer or its bank, is provided by cover of credit risks and risks of change of exchange course;

- functioning of export credit agencies (ECA) - the insurance agencies, banks or departments of ministries, which implement the state policy of export support through insurance of export commercial and political risk guarantees to ensure competitive terms to promote the products/services of domestic firms to international markets, stimulate and provide a guarantee of investment abroad (Belinska, 2008). Thus, they contribute to reducing risks for the bank, which provides financing and helps the recipient of funding to sign a contract with the bank on more favorable terms. The money is returned by the buyer directly to the bank that provided the financing. The creation of ECA today should be one of the 
priority tasks for the government, especially of those countries those that are in a transitional development path of the economy.

Today ECAs operate in more than 100 countries of the world, particularly in Germany (Hermes), Spain (CESCE), Czech Republic (EGAP), Poland (KUKE), France (COFACE), Italy (SACE), Hungary (MEHIB), United States (US Ex-Im), etc. Sometimes functions of ECA are performed by National development banks. According to expert estimates, on average, the ECA can provide an additional 12\% increase in the export of the country, and one additional dollar of ECA budget - approximately $\$ 302$ of additional export (in this case, there is a difference across regions - in OECD, the corresponding figure is \$160) (Sydyachenko, 2002).

The previous list of actions can be expanded, given the specific characteristics of the management system of individual state to enhance the position of the company in the international market. The expansion of export activities puts a task for the country's economy that is to ensure the implementation of potential opportunities of production and competitiveness of the national economy.

\section{Conclusions and suggestions}

The identified components of information provision of the management of international operations and their characteristics that were provided give us possibility to state that while choosing potential partners one needs to examine various aspects of their activities:

legal, i.e. the study of the norms and rules operating in the country of a potential partner and having direct or indirect relation to cooperation;

technological - the study of the technical production level of the firm, its technological base and production capabilities;

scientific and technical - information about the organization of research activities and costs;

organizational - studying organization of enterprise management;

economic - assessment of the financial position of the company.

Effective cooperation in the sphere of foreign economic activities depends on these factors, which proves the necessity of development of methods of analysis and assessment of potential partners in the implementation of international operations.

In turn, stimulation of international operations influences the general development of the economy in the following way: positive);

1) the predominance of exports over imports will be achieved (i.e. net exports will be

2) the share of revenues from foreign operations in the total costs of public economy will increase;

3) the processes associated with the regulation of export-import relations will be monitored twofold: a) on the one hand, by the governmental structures and institutions; b) on the other hand, by the public.

Thus, for the country it becomes possible to go beyond existing limits of its capacity under the condition of increasing the number and improving the quality of the commodity, economic, environmental and social potential. The distribution of funds for lending is becoming the strongest stimulus for the development of export activities and, consequently, economic growth, and plays a significant role in increasing the trust of foreign business and 
investors to domestic companies. This, in turn, will lead to the general improvement of the socio-economic condition of the country.

\section{References}

Belinska, Y. (2008). State support for export: international experience and lessons for Ukraine. Strategic Priorities, 3(8). [in Ukrainian].

De Toni, Alberto F. (2016). International Operations Management: Lessons in Global Business. New York: CRC Press. [in English].

Morel, F. (2013). Go global! But with the right protection. International trade development, No. 11. [in English].

Shihan Xie, Tianyin Cheng, \& Wai-Mun Chia (2013). Trade, finance, specialization and synchronization in the Asia-Pacific. Journal of the Asia Pacific Economy, 18:2, 253-270. DOI: 10.1080/13547860.2013.778160. [in English].

Sydyachenko, C. (2002). Implementation of export development financial instruments in Ukraine, taking into account experience of Export Credit Insurance Corporation of Poland. [Electronic resource]. Retrieved from http://www.tpp. lviv.net/zek/Numbers/1_2002/ Sydiachenko.htm. [in Ukrainian].

Trade Finance Infrastructure Development Handbook for Economies in Transition. (2005). Economic and Social Commission for Asia and the Pacific. World Trade Organization. New York: United Nations publication. [in English].

Tsyomyk, Yu. V. (2006). Improvement of state regulation of export and import in Ukraine in Agricultural Economics. The Economy of Agro-Industrial Complex, No.6, 105-110. [in Ukrainian].

What is Trade Finance? Trade Finance (2013). Euromoney Institutional Investor PLC. [Electronic resource]. Retrieved from http://www. tradefinancemagazine.com/ AboutUs/Stub.html. [in English]. 